\title{
Právní a správní aspekty rozvoje cestovního ruchu v NDR
}

\author{
Lukáš Novotný
}

Filozofická fakulta, Univerzita J. E. Purkyně

Kontaktnie-mail: lukas.novotny@ujep.cz

\section{Legal and Administrative Aspects of Tourism Development in the GDR}

\begin{abstract}
:
In this study we will focus on the issue of tourism in the former GDR. We will observe the legal anchoring of tourism, where we must state, that we cannot only observe in the legal anchoring, but also in the realization, the tradition of organized tourism since the days of Nazism, which also became the inspiration for this socialist state. We will show that the law has only limited this area partially, but this is similar to other parts of the Communist bloc. We will also focus on the administrative aspects of the operation of tourism, specifically on the institutional security of the tourism industry in the GDR. Also, statistics on GDR tourism and geographic assumptions will be outlined.

The study will present both the basic statistical data on tourism in the GDR, as well as the geographical prerequisites for the development of tourism. A separate chapter will cover the legal anchoring of tourism and the interpretation of organizations operating in the tourism industry.
\end{abstract}

\section{Keywords:}

tourism; GDR; planned economy; law; public administratiom; communism

\section{Klíčová slova:}

cestovní ruch; NDR; plánovaná ekonomika; právo; veřejná správa; komunismus

DOI: $10.14712 / 2464689 X .2018 .24$ 
Cestovní ruch v bývalé NDR se vyznačoval několika významnými specifiky, která byla dána celkovým kontextem, v němž tento stát fungoval a existoval. Odehrával se na ekonomickém trhu, který neznal konkurenční prostředí, byl zaměřen hlavně na tuzemský cestovní ruch, protože dovolené v zahraničí nebyly ničím běžným. Navíc bylo obecně cestování zcela zásadně omezené tím, že ho na západ znemožňovala železná opona a Berlínská zed' a také cesty do spřátelených socialistických států byly ztížené různými vízovými povinnostmi. Občané tak byli odříznuti od tradičních prázdninových destinací na jihu Evropy, od pobřeží Strredozemního moře, Alpy musely být nahrazeny horami ve vnitrozemí, včetně např́iklad Krušných hor. Tyto cíle však nutně působily jako slabé náhražky, k nimž však v prostředí reálkomunismu nebyla alternativa. Sice se již i před druhou světovou válkou etablovaly některé destinace, které zůstaly po rozdělení Německa na území NDR, jako například pobřeží Baltu, Krušnohoří, Saské Švýcarsko nebo některá významná kulturní centra (Drážd'any, Výmar), a jejich význam jako turistických center zůstal zachován i v rámci NDR, ovšem celkově vzato rozhodně nelze považovat území NDR za nějakou exponovanou oblast s cíli cestovního ruchu.

A tak se před stranickým aparátem SED (Sozialistische Einheitspartei Deutschlands) v NDR vyjevil významný úkol: učinit z těchto v podstatě druhořadých turistických center naopak místa vyhledávaná. Jinými slovy: objevit v nich atraktivitu a přitažlivost pro své občany. Tohle nebylo třeba učinit jen proto, aby to posloužilo k odpočinku tamních občanů, ale byla to i politická úloha, která se navíc odehrávala v poměrně velkém nepochopení a rozčarování občanů z toho, že musí žít v rozdělené zemi, která je navíc izolována neprodyšnou železnou oponou.

Z každodenní praxe víme, jak důležitou roli sehrávají volnočasové aktivity, jak je třeba vyvažovat work and life a jak je zapotřebí, aby se i dovolená odehrávala v dostatečně atraktivním prostředí. Proto se cílem východoněmeckého režimu stalo to, aby se obyvatelé naučili mít svou zemi rádi jako oblíbený cíl pro trávení svého volného času. Měla tím vzniknout uměle jakási konstrukce o atraktivitě těchto míst, na níž se dá v rámci sociálních věd trefně vztáhnout pojem Thomase Luckmanna o sociální konstrukci reality. ${ }^{1} \mathrm{~K}$ trávení organizovaného volného času mimo ně však neměla být alternativa, což nabourává to, na co jsme zvyklí: totiž že atraktivitu místa, které si zvolíme pro svou dovolenou, si vybíráme sami, že to, kde chceme trávit svůj volný čas, je podmíněno naší volbou. Volba tady neexistovala, bylo jen třeba se ztotožnit s novou představou o tuzemských turistických cílech. Tu se však vytvořit nepodařilo.

Přesto můžeme - avšak se značnou měrou ironie - označit cestovní ruch v NDR za „success story“. Od roku 1946 se již vedly debaty o tom, jak organizovat volnočasové aktivity pro osoby v sovětské okupační zóně. Již od března 1947 vznikla „Prázdninová odborová služba“ (Feriendienst der Gewerkschaften), v létě toho roku již vycestovalo prvních 17500 osob. Za 40 let již tato organizace organizovala dovolené pro 5 miliónů osob v odborových či podnikových zařízeních. Další milióny osob měly to štěstí a směly vycestovat s „Cestovní kanceláŕí NDR“ (Reisebüro der DDR) nebo s „Mládežnickým turistou“" (Jugendtourist) či v rámci podniků. Kvantitativně šlo o nárůst, který byl srovna-

BERGER, L. - LUCKMANN, T. Sociální konstrukce reality: Pojednáni o sociologie vědění. Centrum pro studium demokracie a kultury? Brno: Centrum pro studium demokracie a kultury, 2001; NOVOTNÝ, L. Sociální a komunikativní konstrukce reality - vzpomínka na Thomase Luckmanna. Sociologický časopis / Czech Sociological Review, 2016, roč. 52, č. 4, s. 581-590. 
telný s nárůstem a vývojem ve Spolkové republice Německo. Toto srovnání však samozřejmě pokulhává a je třeba ho vidět v kontextu nekonkurenčního prostředí komunismu.

$\mathrm{V}$ této studii se zaměříme na problematiku cestovního ruchu v bývalé NDR. Budeme sledovat jednak právní úpravu cestovního ruchu, kdy je třeba konstatovat, že můžeme nejen v právním ukotvení, ale i v realizaci sledovat tradici státem organizované turistiky již z dob nacismu, která se stala následnou inspirací i pro tento socialistický stát. Ukážeme si, že právo vymezilo tuto oblast jen částečně, což však je podobné jako i v jiných zemích komunistického bloku. Dále se zaměříme i na správní aspekty fungování cestovního ruchu, konkrétně na institucionální zabezpečení průmyslu cestovního ruchu v NDR. Vyloženy budou však i statistiky k cestovnímu ruchu NDR a geografické předpoklady.

\section{NDR a cestovní ruch}

Cestovní ruch v NDR byl organizován hlavně podniky a státními institucemi. Níže bude vyložena historie Prázdninové odborové služby, která zajistila pobytové zájezdy pro zhruba 2 miliony osob. Dále jmenujme jako poskytovatele kempingová prostranství, která komunistický režim také provozoval, a též Cestovní kancelář NDR a kancelář Jugendtourist pro mladé, která byla založena v roce 1975 . V roce 1989 připadalo 34 procent ubytovacích kapacit na závodové dovolené, 26 procent zahrnovaly kempy, Prázdninová služba poskytla 19 procent a na mládežnické prázdninové pobyty připadlo 17 procent z ubytovacích kapacit. ${ }^{2}$ Do statistik se nezapočítávají individuální cesty a ubytování v soukromých kapacitách, ovšem realita u takovýchto ubytování byla taková, že ceny byly často velmi vysoké, čímž se reagovalo na obrovskou poptávku, kterou se státním institucím nedařilo pokrývat. Typické to bylo naprríklad na ostrově Usedom, což se pak projevovalo i na poměrně velkých problémech se zásobováním a kvalitou služeb.

Pěstovala se také pěší turistika, za níž byl odpovědný Kulturní svaz NDR (Kulturbund der DDR) a konkrétně jeho pracovní skupina „Turistika a pěší turistika“. Asi nejoblíbenější pěší trasou byl „Rennsteig“ v Durynském lese z Hohen Sonne do města Lauscha v samotném východoněmeckém pohraničí. ${ }^{3} \mathrm{~V}$ rámci socialistického bloku pak existovaly i dálkové trasy pro pěší turisty, zejména to byla Mezinárodní horská pěší cesta přátelství Eisenach-Budapešt', která vedla i přes československé území, zejména přes severní hory. ${ }^{4}$

Součástí cestovního ruchu byly samozřejmě i pobyty západoevropských turistů na území NDR, což pro stát přinášelo tolik potřebné devizy. Tito turisté měli několik privilegií, například mohli nakupovat v intershopech, v nichž bylo k mání západní zboží a v nichž nebylo možné platit východoněmeckou markou, ale jen západními měnami.

Pro občany NDR se pak nabízela i možnost vycestovat na dovolenou do některé ze zemí východního bloku, přičemž toto bylo možné pouze s platnými vízy. Cesty do západních zemí byly možné jen ve výjimečných př́padech. Od roku 1973 pak byly umožněny i cesty na Kubu, což se však v praxi týkalo pouze velmi malého počtu osob, ponejvíce funkcionářů strany.

2 WOLTER, H. Ich harre aus im Land und geh, ihm fremd. Die Geschichte des Tourismus in der DDR. Frankfurt: Campus Verlag, 2009, s. 40 a n.

3 KASTNER, M. - RÜGER, U. Rennsteigchronik. Ilmenau: RhinoVerlag, 2009, s. 144.

4 Viz SPODE, H. (ed.). Goldstrand und Teutonengrill. Kultur- und Sozialgeschichte des Tourismus in Deutschland. 1945-1989. Berlin: Moser - Verlag für Universitäre Kommunikation, 1996 (Institut für Tourismus, Berlin. Berichte und Materialien 15). 


\section{Geografické předpoklady tuzemského cestovního ruchu}

Nutnost podporovat turistické aktivity občanů nalezla své určité vědecké opodstatnění v geografii cestovního ruchu a rekreace, která se etablovala ve východoněmecké vědě, konkrétně v ekonomické geografii, od 60. let minulého století. ${ }^{5}$ Cílem těchto „výzkumných“ aktivit bylo podporovat pozitivní stanoviska občanů vůči politice a režimu tím, že jim byla organizovanou formou prostřednictvím odborů poskytována možnost rekreace. ${ }^{6}$ Argumentovalo se však silně politicky v tom smyslu, že se to dělo právě díky státu, straně a režimu, který umožnil občanům organizovanou dovolenou. Tamní geografové se ve výzkumu soustředili na koncept „teritoriálního rekreačního systému“, který definoval Vladimír Sergejevič Preobrazenskij, ředitel Geografického ústavu Akademie věd SSSR. Tento systém byl složen ze čtyř na sobě závislých subsystémů. Ve středu stál člověk. Samostatným subsystémem byl „geokomplex“, tedy krajina s určitým rekreačním potenciálem. Dalším subsystémem byla infrastruktura a dalším pak podniky a zařízení, která sloužila k potřebám cestovního ruchu. ${ }^{7}$

Nejvýznamnějším regionem pro dovolenou v rámci NDR byl Balt, konkrétně politický okres Rostock, který zahrnoval celé území pobřeží Baltského moře, včetně ostrovů Rujána, Usedom nebo Poel. Tento region se vyznačoval dlouhými písčitými plážemi, byl proto vyhledávaným cílem sice primárně východoněmeckých turistů, ovšem nejen jich, ale i např́klad občanů z Československa. Jedním z nejznámějších přímořských center byl Heiligendamm. Balt se tak vyznačoval - řečeno slovy tehdejších geografů turismu a rekreace - „vysokými rekreačními centry“. Sezóna zde probíhala zpravidla od poloviny května do poloviny záríi a tamní města a vesnice tak byla tím, co se v socialistické rétorice nazývalo „vysokým společenským potenciálem“. Faktem však je to, že se rekreace koncentrovala do poměrně malého př́mořského pruhu. Přesto však tento malý region byl každoročně cílem asi třetiny všech osob, které čerpaly dovolenou, se stoupající tendencí. V roce 1962 se jednalo ještě jen o asi 300000 osob, v roce 1987 jich bylo již 1,3 miliónů, a to nezapočítáváme individuální turisty, ani turisty zahraniční, včetně těch z ČSSR. ${ }^{8}$ Pobřeží Baltského moře bylo pro občany NDR finančně příznivou destinací, takže tamní kapacity nedokázaly nikdy zcela uspokojit poptávku. Zájem tedy značně převyšoval možnosti, čímž se ukázalo, že to bylo samo plánované hospodářství, které představovalo viditelnou překážku k tomu, aby se Balt etabloval jako vyhledávaná destinace, která by byla dostupná pro široké masy - jinými slovy pro ty, kdo tam chtěli jet. Probíhala sice hned v několika etapách výstavba nových ubytovacích zařizení, ovšem ta nestíhala též pokrýt poptávku.

Vedle toho se jako turistický region etablovaly hory, at’ už Durynský les, Krušné Hory, Vogtland nebo Labské pískovce v Saském Švýcarsku. V 50. letech 20. století sem směřoval každý druhý turista v NDR, postupně však význam těchto regionů klesal právě na

5 JACOB, G. Modell zur regionalen Geographie des Fremdenverkehrs. Geographische Berichte, 1968, roč. 46 , č. 1 , s. 51-57, zde 51 .

6 BÄHRE, H. Tourismus in der Systemtransformation. Eine Untersuchung zum Reisen in der DDR und zum ostdeutschen Tourismus im Zeitraum 1980 bis 2000, sv. 2. Berlin: Verlag für Weiterbildung im Tourismus, 2003, s. 166 a n.

7 HENNINGSEN, M. Der Freizeit- und Fremdenverkehr in der (ehemaligen) Sowjetunion unter besonderer Berücksichtigung des Baltischen Raums (Europäische Hochschulschriften, řada XVII, sv. 6). Frankfurt: suhrkamp, 1994, s. 17 a n.

8 Statistisches Jahrbuch der DDR 1988, s. 336. - BEST, H. Sozialismus in der DDR: ein Feldexperiment mit paradoxalem Ergebnis. Historical Social Research, Supplement. 2008, č. 20, s. 165-194. 
úkor Baltského moře. Podíl turistů v roce 1988 činil 27 procent. Určitou výhodou zde byla možnost využívat tamní kapacity fakticky po celý rok, včetně zimy. Krom toho panovaly v těchto regionech, konkrétně v okrscích Gera, Suhl, Karl-Marx-Stadt a Drážd'any, př́íznivější podmínky pro budování ubytovacích a jiných rekreačních kapacit. Ovšem problémy s uspokojením poptávky se objevovaly i zde. Tyto regiony sehrávaly vedle toho jistou roli také pro blízkou rekreaci, chatařství atd. Není jistě zcela bez zajímavosti i to, že v různých textech se objevovaly i některé zcestné historické nepravdy, např́iklad o tradici saského horolezectví a turistických spolků, u nichž byl kladen do popředí jejich boj proti nacismu. ${ }^{9}$

Další významnou oblastí byla meklenburská a braniborská jezera, oblast středního Polabí, Magdebursko, lázeňská města a další menší rekreační oblasti. ${ }^{10}$

Naopak režim dbal velmi na to, aby ta místa, která jeho občané znali z doby před rozdělením Německa, byla prezentována v negativním světle. Města jako Bad Kissingen, Garmisch-Partenkirchen nebo Bad Salzuflen tak byla dehonestována jako místa, která podle vyjádření v propagandě NDR slouží k relaxaci okupačních jednotek revanšistů. Bylo se tak možné dočíst o tom, že západoněmecké lázně Oeynhausen mají být obehnané drátem a tím odříznuty od světa, že tamní lázeňské domy mají chátrat atd. Podobná negativní propaganda a zcela imaginární fantazie zaznívala také na další místa, například na jezero Wannsee v západním Berlíně.

Toto byla propaganda, která byla velmi častá ze strany Feriendienstu. ${ }^{11}$ Velké trauma bylo spojené s ostrovem Helgoland, který býval „, dobách míru oním proslaveným ostrovem, který byl cílem desetitisíců turistů“. V dobách NDR byl však prezentován jako opuštěný ostrov, který slouží jako vojenské cvičiště pro britské letectvo. Naopak východoněmecké ostrovy a pobřeží Baltu bylo vykreslováno jako přesný protiklad těchto míst, na nichž se „nemohou pohybovat ani rybáři se svými loděmi, natož turisté“. Na Usedomu se dokonce jako připomínka na starý dobrý Helgoland pojmenovalo jedno z ubytovacích zařízení „Heim Helgoland“.

\section{Instituce cestovního ruchu}

Tou první je „Prázdninová odborová služba“ (FDGB-Feriendienst), což byla organizace odborů NDR, která vznikla již v roce 1947 ještě v rámci sovětské okupační zóny. Jejím cílem bylo zprostředkovat pracujícím subvencovanou tuzemskou dovolenou. ${ }^{12}$ Tato organizace navazuje na dřivější praxi zajišt'ování kolektivních dovolených $\mathrm{z}$ doby nacismu, kdy tehdy tuto úlohu sehrávala organizace „Radostí k síle“ (Kraft durch Freude, KdF), jejíž vznik je doložen již v listopadu 1933. ${ }^{13}$ Tato tradice samožrejmě nebyla nijak veřejně zmiňovaná, ovšem způsob organizování volného času v době nacismu zůstal řadě lidí ještě v paměti.

\footnotetext{
9 GÖRLICH, Ch. Urlaub vom Staat. Tourismus in der DDR. Köln: Böhlau, 2012, s. 203, s. 84.

10 GODAU, A. Das Kur- und Bäderwesen der DDR - Bestandteil des Tourismus und des sozialistischen Gesundheitsschutzes. Revue de tourisme, 1989, č. 4, s. 21-22.

11 GÖRLICH, Urlaub vom Staat. Tourismus in der DDR, s. 203, s. 60.

12 SCHAUFUSS, T. Die politische Rolle des FDGB-Feriendienstes. Berlin: Duncker \& Humblot, 2011, s. 34.

13 KRÜGER, A. Strength through joy. The culture of consent under fascism, Nazism and Francoism. In: RIORDAN, J. - KRÜGER, A. (eds.). The International Politics of Sport in the 20th Century. London: Spon, 1999, s. 67-89.
} 
Cestovní ruch v NDR se vyvíjel po sovětském vzoru. Ústava NDR zakládala nárok na placenou roční dovolenou. V článku 34 ústavy z dubna 1968 stojí: „Každý občan NDR má právo na volný čas a odpočinek. Právo na volný čas a odpočinek je zajištěno zákonným omezením denní a týdenní pracovní doby, plně hrazenou roční dovolenou a plánovanou výstavbou sítě lidových a jiných společenských odpočinkových a prázdninových center.“

Toto tvrzení z ústavy však bylo po dlouhou dobu fakticky velmi omezeno s jistým motivačním charakterem, a to pouze na ty, kteří dost pracovali v podniku nebo ve prospěch strany. Např́íklad dovolená pro rodiny nebyla připuštěna, ${ }^{14}$ podobně také dovolenkové programy pro důchodce byly umožněny až od roku $1977 .{ }^{15}$

Stát nedisponoval dostatkem peněz proto, aby uspokojil poptávku všech těch, kdo požadovali vyjet na dovolenou. ${ }^{16} \mathrm{~V}$ roce 1953 byla realizována „Akce růže“, jejímž cílem bylo zestátnit ubytovací zařízení a následně tím značně rozšiřit nabídku ubytovacích zařízení Prázdninové odborové služby. ${ }^{17}$ Ta byla jen jedním z poskytovatelů dovolených, vedle podniků a také například státních kempingových prostranství. V roce 1984 poskytovaly podniky na 413000 míst, Prázdninová služba 135900 , nejčastěji na Baltu, ale i v pohořích. ${ }^{18}$ Prázdninová služba pak krom toho provozovala výletní lodě (MS Arkona, Fritz Heckert, MS Völkerfreundschaft). V podnicích se poskytovaly prázdninové šeky (Ferienchecks). Poptávka po nich byla skutečně veliká, mimo jiné i proto, že se občané NDR snažili fungovat podobně jako občané v SRN, což však fakticky nebylo možné. Luxusní tuzemská dovolená byla možná např́íklad v hotelu Neptun ve Warnemünde. Ovšem od 60. let se začal projevovat nedostatek devíz, který tento typ dovolených, ale i například lodních pobytů značně omezil. ${ }^{19}$ Financování se realizovalo jednak z prostředků Prázdninové služby, ale také z příspěvků samotných účastníků těchto dovolených a ze státního rozpočtu. Pro orientaci: v roce 1989 se takto vydalo zhruba 550 miliónů východoněmeckých marek. ${ }^{20}$

Dále zde působil „Jugendtourist“, tedy mládežnická cestovní kancelář, ustanovená $\mathrm{v}$ roce 1975, jejímž cílem bylo organizovat a podporovat turistiku mladých do 27 let, a to

14 Až v polovině 60. let se situace v prorodinné politice proměnila natolik, že byl přijat zákoník o rodině (Familiengesetzbuch), v němž stojí, že „rodina je základní buňkou společnosti“, který posílil nejen úlohu rodiny v sociální politice, ale také navýšil právě možnosti rodin na účasti na organizovaných dovolených. Familiengesetzbuch der Deutschen Demokratischen Republik, 20. prosinec 1965. In: Gesetzblatt der Deutschen Demokratischen Republik 1966, část I, s. 1-18, zde 1. Dále také GERHARD, U. Die staatlich institutionalisierte »Lösung« der Frauenfrage. Zur Geschichte der Geschlechterverhältnisse in der DDR. In: KAELBLE, L. et al. (ed). Sozialgeschichte der DDR. Stuttgart: Klett-Cotta, 1994, s. 383-403, zde 389.

15 GÖRLICH, Urlaub vom Staat. Tourismus in der DDR, s. 203.

16 SATTLER, F. Wirtschaftsordnung im Ubergang. Politik, Organisation und Funktion der KPD/SED im Land Brandenburg bei der Etablierung der zentralen Planwirtschaft in der SBZ/DDR 1945-52 (Diktatur und Widerstand, sv. 5), část 1. Münster: LIT Verlag, 2001, s. 106; WEHLER, H.-U. Deutsche Gesellschaftsgeschichte, sv. 4: Vom Beginn des Ersten Weltkriegs bis zur Grundung der beiden deutschen Staaten 1914-1949. Mnichov: C. H. Beck, 2003, s. 939; STEINER, A. Von Plan zu Plan. Eine Wirtschaftsgeschichte der DDR. Mnichov: DVA, 2004, s. 19; ABELSHAUSER, W. Deutsche Wirtschaftsgeschichte seit 1945. Mnichov: DVA, 2004, s. 60.

17 Viz MÜLLER, K. Die Lenkung der Strafjustiz durch die SED-Staats- und Parteiführung der DDR am Beispiel der Aktion Rose. Frankfurt/M.: Suhrkamp, 1995.

18 SCHAUFUSS, T. Die politische Rolle des FDGB-Feriendienstes. Berlin: Duncker \& Humblot, 2011, s. 50.

19 Heslo „Urlauberschiff“. In: DOWE, D. (ed.). FDGB-Lexikon. Funktion, Struktur, Kader und Entwicklung einer Massenorganisation der SED (1945-1990). Berlin: Friedrich-Ebert-Stiftung, 2009.

20 Zeit online: DDR-Geschichte: Die Festung Rügen. Online dostupné na: http://www.zeit.de/2013/12/ Ruegen-DDR-Flottenbasis/komplettansicht. 
jak tuzemskou, tak i zahraniční do spřátelených socialistických zemí. Pro mladé se organizovaly letní prázdninové tábory, které známe i z komunistického Československa. Je jistou zajímavostí, že Jugendtourist kooperoval s Deutsches Jugendherbergswerk, západoněmeckou mládežnickou organizací, a to mimo jiné i na tom, aby se mohli mladí lidé ze západu ubytovávat v zařízeních, která Jugendtourist spravoval. ${ }^{21}$

Cesty do zahraničí zprostředkovávala „Cestovní kancelář NDR“ (Reisebüro der DDR). Byla to jediná cestovní kancelář, která měla pobočky v rámci celé země. Zde bylo možné si zakoupit jízdenky na vlak nebo letenky a cestovní kancelář nabízela též cestovní nabídky v tuzemsku. Těžiště činnosti však leželo na zprostředkovávání dovolené v socialistických zemích. Cestovní kancelář uzavírala smlouvy s jinými cestovními kancelářemi v těchto zemích a v nich stálo, kolik turistů z NDR smí ročně navštívit danou zemi, ale také to, kolik turistů ze spř́teleného zahraničí smí do NDR přijet. Dovolené se organizovaly pro skupiny až po 40 osobách, které měly zajištěného průvodce. Cestovní kancelář tak zaměstnávala poměrně velké množství turistických průvodců. Zajišt'ovaly se bud' zájezdy s individuálním programem, nebo s organizovaným programem. ${ }^{22}$

Dovolenkové pobyty poskytovaly prostor pro „ideologizaci“, díky svému kolektivnímu duchu měly za cíl posilovat pracovní disciplínu a svou strukturou a ideologickým rozměrem, který byl součástí organizovaných částí těchto pobytů, měly vytvořit prostor pro budování nového politického systému, v němž to měly být právě tyto volnočasové aktivity, které měly být „,viditelným výrazem našeho proletářského státu“. ${ }^{23}$

\section{Právní ukotvení cestovního ruchu v NDR}

Již zde bylo uvedeno, že cestovní ruch v NDR se vyvíjel po sovětském vzoru. Zmínka o podpoře rekreace se nacházela i v Ústavě NDR z roku 1968, která předpokládala dokonce placenou roční dovolenou. V článku 34 ústavy z dubna 1968 stojí: „Každý občan NDR má právo na volný čas a odpočinek. Právo na volný čas a odpočinek je zajištěno zákonným omezením denní a týdenní pracovní doby, plně hrazenou roční dovolenou a plánovanou výstavbou sítě lidových a jiných společenských odpočinkových a prázdninových center.“

Již v sovětské okupační zóně se hledaly cesty, jak vykompenzovat pracujícím osobám špatné pracovní podmínky dodatečným příspěvkem na dovolenou. První právní úprava o zachování práv pracujících a o odměnění pracovníků pochází z 20. května 1953 a následně i obdobné nařízení z 6 . srpna $1953 .{ }^{24}$ Zajišt'ovaly se tím zdroje pro osoby pracující v těžkých podmínkách. Tyto př́spěvky jim byly poskytovány prostřednictvím rámcových kolektivních smluv. Jako př́klad můžeme uvést rámcovou kolektivní smlouvu pro ministerstvo dopravy, pro podniky působící v oblasti stavby silniční sítě z roku 1952. V určitých př́padech činily rizikové příspěvky až 25 procent ze mzdy, které připadaly dokonce úředníkům na ministerstvu práce a sociálních věcí jako př́liš vysoké. Dne 7. června 1951 vyšlo nařízení o dovolené (Verordnung zum Erholungsurlaub), a dále pak 1. června 1961

21 Bibliographisches Institut Leipzig (ed.). BI-Universallexikon A-Z. Lipsko, 1988, heslo „Jugendtourist““, s. 355; PAPADOGIANNIS. Keeping with Contemporary Times': Social Tourism and West German Youth Hostel Organizations, 1950s-80s. Journal of Contemporary History, 2016, roč. 51, č. 3, s. 660-687.

22 GÖRLICH, Ch. Zur DDR-Reisezeitschrift „Unterwegs“ 1957-1962. In: TIMMERMANN, H. (ed.). Die DDR in Europa - zwischen Isolation und Öffnung. Münster: LIT Verlag, 2005, s. 506-527, zde 514.

23 GÖRLICH, Urlaub vom Staat. Tourismus in der DDR, s. 45.

24 GB1. der DDR, s. 377, s. 925. 
nařízení o změně nařízení o dovolené, podle něhož měly opět zejména osoby, které pracovaly v rizikových povoláních, nárok na dovolenou o 18 až 24 dnech. ${ }^{25}$

Zmínka o cestovním ruchu je dále i v Zákonu o místních lidových zastoupeních v Německé demokratické republice ze 4. července $1985 .{ }^{26} \mathrm{~V} \S 3$ čl. 3 tohoto zákona se zmiňuje nutnost těchto zastoupení zajišt'ovat kulturní a materiální potřeby občanů, starat se o politiku bydlení, zásobování občanů, a dále zde stojí, že „místní lidová shromáždění dohlížejí na ochranu přírody, zahrnují další možnosti pro odpočinek a turismus, stejně jako tělesnou kulturu a sport, zajišt'ují medicínské a sociální služby občanů a ovlivňují také zdravotní a pracovní ochranu a pracovní kulturu.“

V zákonech a nařízeních se objevují vždy fakticky pouze zmínky o cestovním ruchu, takže nemůžeme hovořit o nějakém uceleném právním zajištění této agendy. V Zákonu o právech odborů v Německé demokratické republice (Gesetz über die Rechte der Gewerkschaften in der Deutschen Demokratischen Republik) se v 114 píše: „Odbory mají právo organizovat vlastní Prázdninovou službu." V zákoníku práce NDR (Arbeitsgesetzbuch der Deutschen Demokratischen Republik) ze dne 16. června 1977 nalezneme $\S 14$ Rámcové kolektivní smlouvy. V bodě 1 zde stojí: „V rámcových kolektivních smlouvách se domlouvají zvláštní nařízení o pracovní mzdě a dovolené a také další pracovněprávní nařízení, zvláště v souvislosti se zintenzivněním produkce.“

Cestovní ruch mladých měla na starosti Svobodná německá mládež (FDJ). Ta ovšem již ztratila na základě Zákona o mládeži v roce 1950 výlučný vliv na tyto dovolenkové programy, poněvadž tento zákon umožnil vedle FDJ ,podporu cestování mladých a dětí všem orgánům státní správy“. V tom tedy vidíme, že na rozdíl od dovolenkových aktivit pro dospělé se turismus pro mladé lidi stal poměrně brzo po vzniku NDR úkolem celostátního významu. Tím však byly položeny základy zpočátku poměrně chaotické struktury, v níž nebylo po dlouhou dobu zcela jasné, kdo že tedy je za tuto složku cestovního ruchu vlastně odpovědný. Podílely se na něm vedle FDJ také „oddělení pro kulturní masovou práci“ při odborech a další masové organizace jako např́klad Společnost pro sport a techniku (GST), Kulturní svaz a Německý tělocvičný a sportovní svaz (DTSB), ale také organizace při podnicích. Tato situace nebyla pro FDJ nijak výhodná, proto vyvíjela tlak na stranické orgány, což se nakonec v 70. letech podařilo, a tak vznikl „Jugendtourist“. Přesto je však na místě podotknout, že FDJ se až do zániku NDR nepodařilo se etablovat jako jediná organizace ovlivňující zájezdy mladých.

\section{Závěr}

Páteř cestovního ruchu v NDR tvořily fakticky pouze dovolenkové pobyty pracujících občanů. Jestliže platí, že cestování je do jisté míry naším „únikem z každodennosti“, tak v tomto př́padě nebylo ale úplně možné ,prchnout“ tam, kam si občané přáli, a nešlo ani zcela prchnout před zpolitizovaným každodenním světem. Na druhou stranu se jim právě díky dovolené naskytla možnost vycestovat $\mathrm{z}$ měst a alespoň zčásti tak zmizet ze světa, jemuž dominoval všudypřítomný stát a strana. Ovšem je třeba vidět to, že život v NDR

\footnotetext{
25 WIENHOLD, L. Arbeitsschutz in der DDR. Kommunistische Durchdringung fachlicher Konzept. Hamburg: disserta Verlag, 2014, s. 153.

26 Gesetz über die Selbstverwaltung der Gemeinden und Landkreise in der DDR vom 17. Mai 1990 (GB1. I S. 225).
} 
byl skutečně značně zpolitizovaný, a tím logicky musely tyto politické tlaky působit i na dovolenkové pobyty a zájezdy. Organizace působící v průmyslu cestovního ruchu se však od silné ideologizace v 50. letech 20. století později přeci jen trochu odvrátily, natolik si uvědomovaly, že během dovolených se může ukázat jako kontraproduktivní, pokud by se zde působilo přehnaně ideologicky.

Prázdninová služba působící při odborech se tak proměnila v jakýsi západoněmecký „Neckermann“, snažila se fungovat ,jako“ západní cestovní kanceláře a nabízet destinace ze socialistického světa. A i občané si zvykli pragmaticky na to, že k tomu, aby na ně „vybyly“ dobré cestovní cíle, se od nich vyžaduje často určité konformní chování. Zejména za reformních snah v sociální politice za Honeckera se uvolnily z rozpočtu finance proto, aby se investovalo do zkvalitnění nabídky ubytovacích zařízení a aby se navýšil počet lůžek. Ovšem v tom, co režim dělal a jak se sice snažil, ale jak to nebylo nikdy dost, se ukázala absurdita celého průmyslu cestovního ruchu v NDR. Zásadním problémem bylo, že se fakticky nikdy v plánované ekonomice nepodařilo uspokojit přání účastníků cestovního ruchu. Plánovaná ekonomika se tak ukázala jako neschopná umět vytvořit uspokojivou nabídku.

Prázdninová služba a její zaměstnanci byli poměrně intenzivně konfrontováni s požadavky a kritikou cestujících. Museli sice nadále zohledňovat ideologicko-politická kritéria, a to jak při výběru cestujících, tak i při organizaci jejich zájezdů, ovšem zejména jejich průvodci, ale i hoteliéři se po 60 . letech proměnili v osoby, které se snažily upozadňovat tato ideologická kritéria a kterým začalo především záležet na dobrých službách pro občany. Dobrých službách v rámci možností.

Průmysl cestovního ruchu se ještě v 50. letech zaměřoval na ideologické vymezování vůči západu. Od 60. let ale tato konfrontační ideologizace oslabovala, ostatně i například v letoviscích se již tolik neakcentovala nutnost ,uskutečnit socialismus“ (Verwirklichung des Sozialismus), ale začal se v rámci možností klást větší důraz na uspokojování přání účastníků cestovního ruchu. Je třeba si uvědomit, že lidé, kteří zde pracovali, fungovali nejen pro domorodé obyvatelstvo, ale i pro západní hosty. Byli tedy konfrontováni is jejich životní realitou a standardy. Ovšem platilo, že dovolená ,nikdy nebyla tím pěkným protikladem vůči šedé každodennosti“" a že „nikdy neznamenala odstřihnout se od politiky“. ${ }^{27}$

Cestovní ruch byl sice v NDR právně ukotven, ovšem pouze na nejminimálnější úrovni. Nemělo smysl v plánované ekonomice a v podmínkách, v nichž neexistovala konkurence, tuto oblast regulovat. V Ústavě sice byla zmínka o nároku na dovolenou, ovšem realizace v konkrétních podmínkách již byla komplikovanější. Stejně tak sice existovaly instituce, které působily ve prospěch průmyslu cestovního ruchu, ovšem jejich funkčnost, schopnosti a možnosti se vůbec nedaly srovnat s realitou cestovních kanceláří či agentur na západě. $\mathrm{S}$ dnešním odstupem několik desetiletí a také se znalostí socialistických poměrů v komunistickém Československu tak lze konstatovat, že průmysl cestovního ruchu ve východním bloku obecně, a tedy i v NDR, značně zaostával. Na druhou stranu plnil či se snažil plnit rekreační a volnočasové potřeby občanů. Že se to nedařilo, leželo logicky na velmi omezených možnostech a na neexistenci konkurenčního prostředí.

27 GÖRLICH, Urlaub vom Staat. Tourismus in der DDR, s. 266. 